\section{HOLOCENE PALEOENVIRONMENTAL AND PALEOCLIMATIC CHANGES FROM THE NGAOUNDABA PEAT DEPOSIT (NORTH CAMEROON)}

GDGT-based temperature and $\mathrm{pH}$ are coherent with insolation variation and with pollen-based records from Lake MBalang [3], situated $20 \mathrm{~km}$ to the north of NGaoundaba. $\delta^{13} \mathrm{C}_{\mathrm{n} \text {-alk, }} \delta \mathrm{D}_{\mathrm{n} \text {-alk }}$ and $\delta^{13} \mathrm{C}$ of hopanoids will complement this work and provide indications of past variations in vegetation, palaeohydrology and methanotrophy, respectively.

[1] Ficken et al. (2000) Organic Geochemistry 31, 745-749.

[2] Naafs et al. (2017) Geochimica et Cosmochimica Acta 208, $285-301$.

[3] Vincens et al. (2010) Clim. Past 6, 281- 294.

\author{
VALENTINE SCHAAFF ${ }^{1}$, MATTHEW MAKOU ${ }^{2}$, \\ VINCENT GROSSI ${ }^{3}$, SALOMÉ ANSANAY-ALEX ${ }^{2}$, INGRID \\ ANTHEAUME $^{2}$, PIERRE DESCHAMPS ${ }^{4}$, BRUNO \\ HAMELIN $^{4}$, YANNICK GARCIN ${ }^{5}$, DAVID SEBAG ${ }^{6}$, \\ BENJAMIN NGOUNOU NGATCHA ${ }^{7}$ AND GUILLEMETTE \\ MÉNOT $^{2}$ \\ ${ }^{1}$ Laboratoire de Géologie de Lyon, Univ Lyon \\ ${ }^{2}$ LGLTPE, Univ Lyon, ENS de Lyon, Université Lyon 1, CNRS \\ ${ }^{3}$ LGLTPE, \\ ${ }^{4}$ CEREGE, Aix Marseille Univ, CNRS, IRD, INRAE, Coll \\ France \\ ${ }^{5}$ CEREGE, Aix Marseille Univ, CNRS, IRD, INRAE, Coll \\ France, CEREGE UMR 7330 \\ ${ }^{6}$ IFP Energies Nouvelles, Direction Sciences de la Terre et \\ Technologies de l'Environnement, 1 et 4 avenue de Bois-Préau \\ 92852 Rueil-Malmaison \\ ${ }^{7}$ LAMISE, University of NGaoundéré, NGaoundéré \\ Presenting Author: valentine.schaaff@ens-lyon.fr
}

Peat deposits have a high potential for paleoclimate and paleoenvironmental reconstruction, as these organic-rich sediments may preserve a high abundance and great diversity of organic matter such as pollen, plant macrofossils or biomarkers. In this study, we investigate a 6-meter peat core from the NGaoundaba peatland (Northeastern Cameroon) over the last 10 ka by using a large panel of lipid biomarkers [Isoprenoid and branched glycerol-dialkyl-glycerol-tetraethers (isoGDGT and brGDGT respectively), $n$-alkanes, hopanoids and degradation products of plants]. This work provides a new paleoenvironmental and paleoclimatic record for tropical Africa over the Holocene covering the end of the African Humid Period. Furthermore, this multi-biomarker study will provide an opportunity to compare different recently developed peat-based proxies and to evaluate their applicability in reconstructing abrupt climatic variations in the tropics.

A diverse assemblage of lipid biomarkers was detected: $\mathrm{C}_{19}$ to $\mathrm{C}_{37}$ n-alcanes, $\mathrm{C}_{27}$ to $\mathrm{C}_{31}$ hopanes and hopenes, both regular and H-GDGTs (both brGDGT and iso-GDGT), among others. These lipid biomarkers present distinct distribution and concentration variations over depth. $n$-alkane-based indexes present interesting variations, which may be related to changes in peatland vegetation and hydrology. In the NGaoundaba peat deposit, the highest $\mathrm{P}_{\mathrm{aq}}$ (ratio of aquatic to terrestrial plant inputs) values, indicating a significant contribution from submerged and/or floating macrophytes [1], can be found around $8 \mathrm{ka}$, which is consistent with the wetter conditions that peaked during the middle of the African Humid Period. Recent peat-specific temperature and $\mathrm{pH}$ calibrations based on brGDGTs [2] were applied to the NGaoundaba peatland stratigraphic record. 